ПИЛИПчУк Н.П.

\title{
ХАРАКТЕРИСТИКА МІЖНАРОДНИХ НОРМАТИВНО-ПРАВОВИХ АКТІВ, У ЯКИХ РЕГУЛЮСТЬСЯ ПРАВО НА ВІДПОЧИНОК
}

У статті проаналізовано міжнародні норми, які регулюють право на відпочинок. Деталізовано зміст основних міжнародних нормативно-правових актів, у яких регулюється право на відпочинок. Наведено наукові позиції у досліджуваному контексті. Перелічено особливості цих нормативно-правових актів. Сформульовано обгрунтовану авторську систему міжнародних стандартів права на відпочинок (відпустку). Наголошено, що основним завданням директив Європейського Союзу як міжнародних стандартів прав на відпочинок $є$ врегулювання національного законодавства відповідно до вимог законодавства Європейського Союзу, зокрема працівникам державних органів доручено забезпечити відповідність проектів законодавчих актів законодавству Європейського Союзу і визначити ступінь їх відповідності Угоді про асоціацію між Україною та Європейським Союзом і законодавству Європейського Союзу. Вивчення міжнародного досвіду реалізації права на відпочинок, особливо найбільш закріпленого його виду - права на відпустку, дозволяє стверджувати, що основною метою міжнародно-правового регулювання у цій сфері $є$ постійне підвищення рівня гарантії реалізації прав працівників на відпочинок. Це проявляється у закріпленні в новоприйнятих міжнародних стандартах більш високої мінімальної тривалості щорічної оплачуваної відпустки, обмеженні вимог до стажу роботи як умови виникнення права на відпустку, у встановленні граничних термінів перенесення відпустки, мінімальної сплати за час відпусток, детальних правил обчислення стажу для відпустки, порядку реалізації права на відпустку при звільненні. Зроблено висновок, що міжнародні стандарти права на відпочинок сьогодні $є$ належним чином імплементованими у вітчизняну правову систему. Як засвідчило наше дослідження, здебільшого норми законодавства України відповідають положенням міжнародних стандартів. Окрім того, найважливіші міжнародні нормативно-правові акти у цій сфері були ратифіковані в нашій державі та $€$ частиною національного законодавства. Тож вивчення міжнародного законодавства у сфері праці підтверджує думку, що правове регулювання права на відпочинок в Україні відповідає світовим стандартам.

Ключові слова: міжнародні норми, право на відпочинок, конституційне право, конституційні норми, конституція.

In the article the international rules governing the right to rest are analyzed. The content of the main international normative legal acts regulating the right to rest is detailed. Scientific positions in the investigated context are presented. The list of peculiarities of these legal acts is presented. The author's system of international standards for the right to rest (vacation) is formulated. It is emphasized that the main task of the European Union directives as international standards for the right to rest is to regulate national legislation in accordance with the requirements of the legislation of the European Union and European Union and European Union legislation. It is found that studying the international experience of exercising the right to rest, especially the most secured one - the right to leave, indicates that the main purpose of international legal regulation in this area is to constantly increase the level of guarantee of the rights of workers to rest. This is reflected in the consolidation in the newly adopted international standards of higher minimum duration of annual paid leave, limitation of requirements for length of service as a condition for the emergence of the right to leave, setting deadlines for transferring leave, minimum

( С ПИЛИПЧУК Н.П. - аспірантка (Інститут держави і права імені В.М. Корецького Національної академії наук України) 
payment for vacation time, detailed rules for calculating leave the right to leave on release. It is concluded that the international standards of the right to rest are now properly implemented in the domestic legal system. According to our research, in most cases, the norms of Ukrainian legislation are in line with international standards. In addition, the most important international legal acts in this field have been ratified in our country and are part of the national legislation. Therefore, a study of international labor law has shown that the legal regulation of the right to rest in Ukraine meets world standards.

Key words: international norms, right to rest, constitutional law, constitutional norms, constitution.

Вступ. Застосування нормативних актів на практиці часто призводить до низки проблем, зумовлених, зокрема, тим, що в чинну законодавчу базу перейшло багато «застарілих» правових норм, які не відповідають сучасному розвитку державності. Окрім цього, норми закону можуть неправильно застосовуватися або ж сам по собі закон може бути недосконалим. Задля вирішення такої ситуації необхідно дослідити деякі міжнародно-правові акти та проаналізувати їхні окремі положення з метою формулювання дефінітивних норм відпочинку і визначення особливостей його окремих видів. Аналіз міжнародних стандартів права на відпочинок дозволить: по-перше, дослідити те, якою мірою міжнародні стандарти права на відпочинок є сьогодні частиною національного законодавства; по-друге, встановити, які міжнародні стандарти права на відпочинок мають стати частиною національного законодавства; по-третє, зробити висновки про те, врахування якої позитивної міжнародної практики допоможе виробити новий, ширший погляд на вирішення проблем вітчизняного трудового та конституційного права, пов'язаних із правом на відпочинок.

Питанням міжнародно-правового регулювання права на відпочинок приділили увагу багато українських вчених, а саме: В.Д. Авескулов, М.М. Антонович, Ю.В. Баранюк, Н.Б. Болотіна, Н.М. Вапнярчук, В.С. Венедиктов, В.М. Венедиктова, О.С. Гапон, Л.П. Гаращенко, К.І. Дмитрієва, В.М. Завгородня, О.В. Ільєнко, Н.І. Іщенко, О.Д. Карпенко, І.Я. Кисельова, І.І. Лукашук, Л.А. Луць, А.Р. Мацюк, Н.М. Пархоменко, П.Д. Пилипенко, С.М. Прилипко, В.І. Прокопенко, О.І. Процевський, В.Г. Ротань, Б.С. Стичинський, Н.М. Хуторян, Г.І. Чанишева, О.М. Ярошенко. Водночас у більшості перерахованих праць досліджувалися загальні питання, такі як міжнародні стандарти у сфері праці чи міжнародні стандарти у сфері робочого часу. Робіт, присвячених міжнародним стандартам права на відпочинок, сьогодні не так багато, а отже, це питання не втрачає своєї актуальності за сучасних умов.

Результати дослідження. Як зазначає К.С. Тищенко, міжнародно-правові стандарти $є$ результатом тривалої роботи великої кількості держав із вироблення узгоджених позицій у сфері прав людини. Держави спрямовують свою діяльність на дотримання певних універсальних цінностей, забезпечуючи повагу і захист прав людини всіма доступними способами, адже вони відповідальні за виконання своїх зобов'язань у галузі прав і свобод людини перед своїм населенням і міжнародним співтовариством [1, с. 328]. Тому Україна, взявши на себе зобов'язання перед міжнародною спільнотою та українським народом щодо захисту прав і свобод людини і громадянина, зобов'язана беззаперечно дотримуватися їхніх положень. У ст. 9 Конституції України визначено, що чинні міжнародні договори, згода на обов'язковість яких надана Верховною Радою України, є частиною національного законодавства [2]. Це означає, що міжнародні стандарти права на відпочинок $є$ частиною національного законодавства України, якщо вони ратифіковані законодавчим органом нашої держави. Міжнародні стандарти застосовуються в Україні для регулювання суспільних відносин так само, як і норми національного права. Як свідчить ст. 81 Кодексу законів про працю України, якщо міжнародним договором або міжнародною угодою, в яких бере участь Україна, встановлені інші правила, ніж ті, котрі містить законодавство України про працю, то застосовуються правила міжнародного договору або міжнародної угоди [3]. Тобто у законодавстві України закріплено пріоритет міжнародно-правових норм перед нормами національного законодавства, що $є$ визнанням Україною верховенства принципів міжнародного права, в т. ч. і в регулюванні права на відпочинок. Таким чином, у тих сферах, де ратифікація міжнародних стандартів була здійснена у встановленому законом порядку, внутрішнє законодавство України є гармонізованим із міжнародним законодавством. Відповідно, прийняття таких нормативно-правових актів у сфері права людини на відпочинок є свідченням того, що в Україні діють загальновстановлені принципи та напрями забезпечення та захисту права людини на відпочинок. 
Загалом мінімальні гарантії Європейського Союзу, впроваджені у вторинному законодавстві, можуть бути змінені національним законодавством держав-членів або колективними угодами, якщо вони впроваджують сприятливіші для працівника умови у сфері часу відпочинку. Втім, більшість працівників користуються вищими соціальними гарантіями порівняно із закріпленими в законодавстві Європейського Союзу мінімальними стандартами.

Проведений у квітні 2018 р. аналіз відповідності національного законодавства директивам Європейського Союзу з питань безпеки та гігієни праці і трудових відносин, підготовлений у рамках проекту «Зміцнення адміністрації праці з метою покращення умов праці та подолання незадекларованої праці», який впроваджується в Україні у 2017-2019 pр. Міжнародною Організацією Праці за фінансування Європейського Союзу, дає зрозуміти, що рівень відповідності Директиві № 2003/88/ЄЕС від 04 листопада 2003 р. юридичним підходам у сфері щоденного відпочинку та щорічної відпустки становить 0,0\% [4]. Так, мінімальні періоди відпочинку не передбачені у чинному законодавстві України, тоді як норма міжнародного стандарту закріплює, що держави-члени вживають необхідних заходів, щоб забезпечити право кожного працівника на мінімальний період щоденного відпочинку тривалістю 11 послідовних годин впродовж кожних 24 годин. Крім цього, вимогам міжнародного стандарту суперечать норми щодо надання щорічної відпустки. Рівню відповідності суперечать положення про те, що держави-члени вживають необхідних заходів, аби забезпечити право кожного працівника на щорічну оплатну відпустку тривалістю не менше ніж чотири тижні відповідно до умов ії отримання і надання, встановлених національним законодавством та / або практикою, мінімальний період щорічної оплатної відпустки не може замінюватися грошовою компенсацією, за винятком випадку припинення трудових відносин. Це не всі пункти, які суперечать рівню відповідності нормам встановленого міжнародного стандарту Директиві № 2003/88/СЕС від 04 листопада 2003 р. Це означає, що законодавець повинен внести необхідні зміни в законодавство або відповідні доповнення у проект Трудового кодексу.

Отже, проаналізувавши міжнародні нормативно-правові акти, в яких регулюється право на відпочинок, можна сформувати таку систему міжнародних стандартів права на відпочинок (відпустку):

1. Міжнародні стандарти, прийняті Організацією Об’єднаних Націй:

1) Загальна декларація прав людини від 10 грудня 1948 р.;

2) Міжнародний пакт про економічні, соціальні та культурні права від 16 грудня 1966 p.

Україна є членом Організації Об'єднаних Націй, а тому зазначені нормативно-правові акти є частиною вітчизняного законодавства. Роль Загальної декларації прав людини від 10 грудня 1948 р. та Міжнародного пакту про економічні, соціальні та культурні права від 16 грудня 1966 р. полягає у тому, що згідно з їхніми положеннями кожна людина отримала право на відпочинок і дозвілля, включаючи право на розумне обмеження робочого дня та на оплачувану періодичну відпустку. Право на відпочинок визнано однією з першооснов сприятливих і справедливих умов праці. Відповідно, вітчизняне законодавство про працю та про відпустки було прийняте з урахуванням і на основі цих положень.

2. Міжнародні стандарти, прийняті Радою Європи:

1) Європейська соціальна хартія від 18 жовтня $1961 \mathrm{p}$.

До цієї групи міжнародних стандартів віднесено лише один нормативно-правовий акт, який, втім, має важливе значення для регулювання права на відпочинок (відпустку) в Україні. Передусім Європейська соціальна хартія є частиною національного законодавства України, адже була ратифікована у встановленому законом порядку. Згідно з положеннями Свропейської соціальної хартії право на відпочинок включає оплачуваний відпочинок у державні святкові дні, щорічну оплачувану відпустку тривалістю не менше чотирьох тижнів, щотижневий відпочинок, який за можливості має збігатися з днем, що за традиціями або звичаями відповідної країни чи регіону визнається днем відпочинку, а також спеціальну тривалість відпусток для деяких категорій працівників. Національне законодавство України про відпочинок було приведене у відповідність до зазначених положень Хартії.

3. Міжнародні стандарти, які є складовою частиною законодавства Європейського Союзу:

1) Договір про заснування Європейської Спільноти від 25 березня 1957 р.;

2) Консолідовані версії Договору про Європейський Союз і Договору про функціонування Європейського Союзу з протоколами та деклараціями 07 лютого 1992 р.;

3) Хартія Співтовариства про основні соціальні права працівників від 09 грудня 1989 p.

Ці нормативно-правові акти не є чинними в Україні, адже їхня дія поширюється виключно на держави-члени Європейського Союзу. Але водночас їх існування важливе для України у кон- 
тексті євроінтеграційного курсу та потенційного вступу до цієї організації. Міжнародні стандарти, які належать до основоположних актів створення та діяльності Європейського Союзу, є допоміжними правовими актами для держав-членів Свропейського Союзу, норми яких закріплюють вимогу щодо прав кожного громадянина держави-члена на відпочинок.

4. Міжнародні стандарти, прийняті Міжнародною Організацією Праці:

1) Конвенція про застосування щотижневого відпочинку на промислових підприємствах № 14 від 25 жовтня 1921 р.;

2) Конвенція про щорічні оплачувані відпустки № 52 від 24 червня 1936 р.;

3) Конвенція про оплачувані відпустки в сільському господарстві № 101 від 4 червня 1952 р.;

4) Конвенція про умови праці на плантаціях № 110 від 24 червня 1958 р.;

5) Конвенція про оплачувані відпустки № 132 від 24 червня 1970 р.;

6) Конвенцію про оплачувані навчальні відпустки № 140 від 24 червня 1974 р.;

7) Конвенція про щорічні оплачувані відпустки морякам № 146 від 29 жовтня 1976 р.;

8) Конвенція про надомну працю № 177 від 20 червня 1996 р.;

9) Конвенцію про перегляд Конвенції (переглянутої) 1952 р. про охорону материнства № 183 від 15 червня 2000 p.

Особливість цієї групи стандартів полягає у тому, що більшість конвенцій не врегульовують безпосередньо питання відпочинку, а переважно присвячені регулюванню надання оплачуваних відпусток. Україна ратифікувала не всі із розглянутих Конвенцій, але лише окремі, серед яких відзначимо ратифікацію в 1956 р. Конвенції про оплачувані відпустки № 521936 р., у 2001 р. Конвенції про оплачувані відпустки № 132 (переглянуто в 1970 р.), у 2002 р. - Конвенції про оплачувані відпустки № 1401974 р. тощо. Національні нормативно-правові акти у сфері відпочинку та відпусток відповідають нормам ратифікованих конвенцій Міжнародної організації праці, після ратифікації яких Україна проголосила свою готовність дотримуватися міжнародних норм із регулювання державних гарантій права людини на оплачувані відпустки, і які подекуди навіть розширюють права громадян України на відпочинок порівняно з міжнародними стандартами.

5. Міжнародні стандарти, відображені у директивах Європейського Союзу:

1) Директива 93/104/СС про робочий час від 23 листопада 1993 р.;

2) Директива 92/85/ЄЕС про запровадження заходів щодо сприяння поліпшенню безпеки та гігієни праці на роботі вагітних працівниць і працівниць, які нещодавно народили або годують груддю, від 19 жовтня 1992 р.; 2003 p.;

3) Директива 2003/88/ЄС про деякі аспекти організації робочого часу від 04 листопада

4) Директива 2010/18/ЄС про імплементацію переглянутої Рамкової Угоди щодо батьківської відпустки, укладеної з BUSINESSEUROPE, UEAPME, CEEP та ETUC, і скасування Директиви 96/34/СС від 8 березня 2010 р.

Основним завданням директив Європейського Союзу як міжнародних стандартів прав на відпочинок $\epsilon$ врегулювання національного законодавства відповідно до вимог законодавства Європейського Союзу, зокрема працівникам державних органів доручено забезпечити відповідність проектів законодавчих актів законодавству Європейського Союзу і визначити ступінь їх відповідності Угоді про асоціацію між Україною та Європейським Союзом і законодавству Європейського Союзу.

Висновки. Підсумовуючи здійснене дослідження, варто зазначити таке. По-перше, вивчення міжнародного досвіду реалізації права на відпочинок, особливо найбільш закріпленого його виду - права на відпустку, дозволяє стверджувати, що основною метою міжнародно-правового регулювання в цій сфері є постійне підвищення рівня гарантії реалізації прав працівників на відпочинок. Це проявляється у закріпленні в новоприйнятих міжнародних стандартах більш високої мінімальної тривалості щорічної оплачуваної відпустки, обмеженні вимог до стажу роботи як умови виникнення права на відпустку, у встановленні граничних термінів перенесення відпустки, мінімальної сплати за час відпусток, детальних правил обчислення стажу для відпустки, порядку реалізації права на відпустку при звільненні. По-друге, міжнародні стандарти права на відпочинок сьогодні $є$ належним чином імплементованими у вітчизняну правову систему. Як засвідчило наше дослідження, здебільшого норми законодавства України відповідають положенням міжнародних стандартів. Окрім того, найважливіші міжнародні нормативно-правові акти у цій сфері були ратифіковані в нашій державі та $є$ частиною національного законодавства. Тож дослідження міжнародного законодавства у сфері праці засвідчило, що правове регулювання права на відпочинок в Україні відповідає світовим стандартам. 


\section{Список використаних джерел:}

1. Тищенко К.С. Міжнародні стандарти прав людини: поняття та класифікація. Молодий вчений. 2017. № 12 (52). С. 328-331.

2. Конституція України від 28 червня 1996 р. № 254к/96-ВР. Верховна Рада України. URL: https: zakon.rada.gov.ua/laws/show/254к/96-вр (дата звернення: 10.07.2019).

3. Кодекс законів про працю України від 10 грудня 1971 р. № 322-VIII. Верховна Рада України. URL: https: zakon.rada.gov.ua/laws/show/322-08\#n53 (дата звернення: 12.07.2019).

4. Аналіз рівня відповідності національного законодавства вибраним директивам ЄС з безпеки та гігієни праці, трудових відносин (Директива № 2003/88/ЄС Європейського Парламенту та Ради від 04 листопада 2003 р. про деякі аспекти організації робочого часу). Квітень 2018. URL: https: ilo.org/wcmsp5/groups/public/---europe/---ro-geneva/---sro-budapest/ documents/meetingdocument/wcms_627060.pdf (дата звернення: 21.08.2019).

УДК 349.2

DOI https://doi.org/10.32844/2618-1258.2019.6.18

ЧУМАЧЕНКО І.М.

\section{ІСТОРІЯ РОЗВИТКУ ПРАВОВОГО РЕГУЛЮВАННЯ ПРОЦЕСУАЛЬНИХ ПРАВОВІДНОСИН У ТРУДОВОМУ ПРАВІ УКРАЇНИ (У ЧАСИ ІСНУВАННЯ РОСІЙСЬКОЇ ІМПЕРІЇ)}

У статті на основі аналізу наукових поглядів вчених здійснено історико-правовий аналіз розвитку правового регулювання процесуальних правовідносин у трудовому праві України за часів існування Російської Імперії. 3'ясовано, що Кримінальним законодавством 1865 року передбачалося покарання для підбурювачів за припинення робіт по стачці, з 1905 року відповідальність встановлювалася лише за самовільне припинення роботи на підприємствах, які мають суспільне або державне значення, а також в урядових закладах. У 1905 році з'являються перші примирні камери, які складалися із представників сторін та розглядали конфлікти, вони існували і після приходу до влади більшовиків. Наголошено, що законодавство Російської імперії не передбачало норм про порядок вирішення трудових спорів колективного характеру, що було природно в умовах заперечення можливості існування спілок, а отже, і колективного регулювання умов праці. Хоча закон не припускав можливості зміни умов найму, фактичне виникнення конфліктів поміж робочими та підприємцями призвело до появи першої норми, яка стосувалася вирішення трудових спорів. Зроблено висновок, що у період існування Російської Імперії законодавчо визначеного та закріпленого механізму вирішення трудових спорів не існувало, а всі питання у цьому контексті вирішувались судами, рівень корумпованості яких фактично не лишав шансів працівникові на справедливе вирішення такого спору. Однак справедливим буде відзначити, що деякі намагання вирішувати трудові спори у позасудовому порядку все ж таки були наявні, про що яскраво свідчить створення Фабричних комісій у 1882 році. Протягом майже 18 років комісії виконували контрольну та запобіжну функції, тобто їх діяльність спрямовувалась на попередження виникнення трудових спорів (конфліктів) у трудовому колективі. Проте вже у 1900 році на Фабричні комісії було покладено обов'язок виконання примирно-посередницьких функцій. А отже, можна із впевненістю говорити про те, що створення вказаних комісій стало першим кроком на шляху законодавчого закріплення вирішення трудових спорів у позасудовому порядку, що своєю чергою мало суттєвий вплив і на розвиток відповідних процесуальних правовідносин у трудовому праві.

Ключові слова: історія, розвиток, правове регулювання, прочесуальні правовідносини, трудове право, Російська імперія.

(C) ЧУМАЧЕНКО І.М. - доктор юридичних наук, доцент, професор кафедри цивільного права (Запорізький національний університет) 